\title{
Comparison of Three Different Fertigation Strategies for Drip Irrigated Table Grapes - Part II. Soil and Grapevine Nutrient Status
}

\author{
C.L. Howell* and W.J. Conradie \\ ARC Infruitec-Nietvoorbij ${ }^{1}$, Private Bag X5026, 7599, Stellenbosch, South Africa
}

Submitted for publication: April 2012

Accepted for publication: September 2012

Key words: Dan-ben-Hannah, fertilisation, irrigation, crop load, phosphorus

\begin{abstract}
A field trial was carried out in a drip irrigated Dan-ben-Hannah/Ramsey table grape vineyard near Paarl in the Berg River Valley region of South Africa to compare three fertigation strategies. Fertilisers were applied (i) two weeks after bud break, fruit set and post-harvest (LF), (ii) weekly from two weeks after bud break until ten weeks after harvest, except during berry ripening (WF), and (iii) in daily fertigation pulses (DF). Grapevines of all treatments received $c .116 \mathrm{~kg} / \mathrm{ha} \mathrm{N}, 22 \mathrm{~kg} / \mathrm{ha} \mathrm{P}$ and $92 \mathrm{~kg} / \mathrm{ha} \mathrm{K}$ per season. Grapevines of all the fertigation strategies were thinned to obtain a normal and high crop load, which is 26 and 36 bunches per grapevine respectively for Dan-ben-Hannah under the given conditions. In the case of DF, the soil directly beneath the drippers became acidic after three years. Salt also accumulated on the perimeter of the wetted soil volumes. Petiole $P$ of the DF grapevines was $77 \%$ higher than that of the LF and WF grapevines. Daily fertigated grapevines bearing normal crop loads had $20 \%$ to $30 \%$ higher leaf blade $P$ than the LF or WF grapevines. Leaf blade $K$ of the WF grapevines was lower than in the grapevines bearing a normal crop load of the LF and DF strategies. Grapevines bearing high crop loads tended to have lower juice $N$ than grapevines with a normal crop load. Juice $P$ of the DF grapevines was higher than that of the LF and WF grapevines, regardless of crop load. Daily pulse fertigation promoted the accumulation of $N, P$ and $K$ in the berry skins.
\end{abstract}

\section{INTRODUCTION}

Fertigation entails the application of nutrients through irrigation water, which is an increasingly common practice in the South African viticultural industry (Conradie \& Myburgh, 2000). In this study, fertigated Bukettraube grapevines were found to have higher levels of $\mathrm{N}$ in the petioles at fruit set than conventionally fertilised grapevines (Conradie \& Myburgh, 2000). However, less Mg was found in both the leaf blades and petioles of the fertigated grapevines. Neither fertigation nor conventional fertilisation influenced the mineral ions in the grape juice. Reynolds et al. (2005) concluded that weekly fertigation of Concord grapevines from bud burst to véraison increased petiole $\mathrm{N}$ more compared with grapevines that received the same amount of fertiliser applied in two applications (pre-flowering and postfruit set). The uptake of the other elements was not enhanced by either irrigation or fertigation. Fertigation of Niagara grapevines with 46:0:0 (urea) from bud break to flowering, followed by $20: 20: 20$ from fruit set to véraison, increased $\mathrm{N}$ and $\mathrm{P}$ levels in the petioles relative to grapevines fertigated with only 46:0:0 either from bud break, or from when the first inflorescences appeared, to véraison (Reynolds et al., 2005). These results also suggest that the formulation of the nutrient can be of importance, as both treatments received $80 \mathrm{~kg} \mathrm{~N} / \mathrm{ha}$. Christensen et al. (1991) investigated the application rate of $\mathrm{K}_{2} \mathrm{SO}_{4}$ to Thompson Seedless grapevines under drip irrigation, where the fertiliser was applied either as a single application or over eight weeks. In the first year of the trial, $\mathrm{K}$ levels in the petioles during flowering were higher for grapevines that received the single application of $\mathrm{K}_{2} \mathrm{SO}_{4}$. However, by véraison, $\mathrm{K}$ levels in the petioles of grapevines fertilised over eight weeks were greater than those that received the single application. In subsequent years of the study, no differences in petiole $\mathrm{K}$ were observed.

Fertigation may have a negative impact on soil chemistry and grapevine performance. Komosa et al. (1999a) reported that fertigation decreased soil $\mathrm{pH}$ beneath the dripper and resulted in the formation of an accumulation zone of

\footnotetext{
${ }^{1}$ The Fruit, Vine and Wine Institute of the Agricultural Research Council
} 
nutrients approximately $20 \mathrm{~cm}$ to $60 \mathrm{~cm}$ from the dripper. Fertigation by means of micro-sprinklers in a sandy soil near Lutzville in the Lower Olifants River region did not have a negative impact on soil $\mathrm{pH}$, resistance, $\mathrm{P}, \mathrm{Ca}, \mathrm{Mg}, \mathrm{Na}$ or $\mathrm{K}$ when compared to conventional application (Conradie \& Myburgh, 2000). However, drip fertigation in the same soil caused a decreased soil $\mathrm{pH}$ under the drippers and biennial lime applications of $10 \mathrm{t} / \mathrm{ha}$ were needed in the grapevine rows to maintain the soil $\mathrm{pH}$ at acceptable levels (P.A. Myburgh, 2011, personal communication). Similar findings have also been reported for other soils (Komosa et al., 1999a; Treder, 2005). Drip irrigation frequencies for table grapes vary from daily (Myburgh, 2012) to weekly (Saayman \& Lambrechts, 1995; Myburgh, 1996). Daily pulse irrigation and fertilisation according to the plant's requirements allow greater control of plant nutrition, as the concentration and uptake of nutrients in the root zone can be manipulated (Falivene, 2005). Currently, there are very few published results on this fertigation approach.

The objective of this study was to compare the effects of different fertigation strategies on soil chemical and nutrient status in table grapes. In addition, the ability of Dan-benHannah grapevines to sustain higher than recommended normal crop loads, in terms of grapevine nutritional status, was investigated. The effects of these strategies on soil water status, root system characteristics and plant water status have already been reported (Myburgh \& Howell, 2012). Growth, yield and fruit quality responses of Dan-ben-Hannah will be presented and discussed in a subsequent article.

\section{MATERIALS AND METHODS}

\section{Experimental design and layout}

This project was carried out in a commercial drip irrigated Dan-ben-Hannah/Ramsey vineyard near Paarl in the Berg River Valley region of South Africa during the 2001/02, 2002/03 and 2003/04 seasons. The region has a Mediterranean climate and, based on growing degree days from September until March (Winkler, 1962), is in a class V climatic region (Le Roux, 1974). Dan-ben-Hannah, also known as Black Emperor, originated in Israel, where it was selected from a cross between Black Mikveh and Alphonse Lavallee (Hurndall, 2005). Details of the soil, irrigation system and viticultural practices have been described by Myburgh \& Howell (2012). A factorial experiment layout, with three fertigation treatments and two crop load levels, was used (Table 1), and treatments were replicated six times. Each experiment plot consisted of a row of sixteen experiment grapevines with two border grapevines at each end and a border row on each side to minimise the overlap of treatment effects. In each plot, bunches on eight experiment grapevines were thinned to obtain a normal crop load $(\mathrm{N})$, which is 26 bunches per grapevine for Dan-ben-Hannah under the given conditions. The remaining grapevines were thinned less severely to bear a relatively high crop load $(\mathrm{H})$ of 36 bunches per grapevine.

Treatments were applied from two weeks after bud break in September until the end of March, when the first autumn rains occurred. The low frequency fertigated (LF) grapevines received fertiliser two weeks after bud break, at fruit set and again after harvest. Weekly fertigated (WF) grapevines received the same total amount of fertiliser as the LF grapevines, but applied weekly from two weeks after bud break until ten weeks after harvest, except during berry ripening. The third strategy entailed daily pulse fertigation (DF) according to the daily requirements of the grapevines during the various phenological stages (Conradie, 1980; 1981).

Fertigation was controlled by a computer system with specialised software (Eldar Shany, Israel). During the 2002/03 season, two to three irrigations were applied per week from November to March for the LF and WF grapevines, whereas they were irrigated weekly until March in 2003/04 (Myburgh \& Howell, 2012). The soil remained wet at a distance of $100 \mathrm{~mm}$ from the drippers in the DF treatments to a depth of $150 \mathrm{~mm}$, whereas $200 \mathrm{~mm}$ away from the drippers, the soil dried out as the season progressed. In total, $492 \mathrm{~mm}$ and $423 \mathrm{~mm}$ of water was applied to the DF grapevines in 2002/03 and 2003/04 respectively, whilst the LF and WF grapevines received $257 \mathrm{~mm}$ and $266 \mathrm{~mm}$ in 2002/03 and 2003/04 respectively.

The amount of fertiliser applied was in accordance with norms established earlier (Conradie, 1980, 1981). All treatments received comparable amounts of $\mathrm{N}, \mathrm{P}$ and $\mathrm{K}$ (Tables $2 \& 3$ ). Calcium, $\mathrm{Mg}$ and trace elements are

TABLE 1

Fertigation and crop load treatments applied during the 2002/03 and 2003/04 seasons.

\begin{tabular}{llll}
\hline Treatment $^{(1)}$ & Crop load $^{(2)}$ & Fertigation strategy & Irrigation frequency \\
\hline $\mathrm{LF}_{\mathrm{N}}$ & Normal & 3 times/season & weekly \\
$\mathrm{WF}_{\mathrm{N}}$ & Normal & weekly $^{(4)}$ & weekly \\
$\mathrm{DF}_{\mathrm{N}}$ & Normal & daily pulses & daily pulses \\
$\mathrm{LF}_{\mathrm{H}}$ & High & 3 times/season & \\
$\mathrm{WF}_{\mathrm{H}}$ & High & weekly & weekly \\
$\mathrm{DF}_{\mathrm{H}}$ & High & daily pulses & weekly \\
\hline
\end{tabular}

${ }^{(1)} \mathrm{LF}=$ Low frequency, $\mathrm{WF}=$ Weekly fertigation, $\mathrm{DF}=$ Daily pulse fertigation. ${ }^{(2)} \mathrm{N}=$ Normal, i.e. 26 bunches per grapevine, $\mathrm{H}=$ High, i.e. 36 bunches per grapevine. ${ }^{(3)}$ Two weeks after bud break, fruit set and post-harvest. ${ }^{(4)}$ Same amount of fertiliser as LF but applied weekly for six weeks from two weeks after bud break, weekly for six weeks from fruit set to véraison, and weekly for ten weeks post-harvest. ${ }^{(5)}$ Refer to Myburgh and Howell (2012). 
generally not applied by fertigation. Since the small wetted volumes might not have been able to supply all the nutrient requirements of the grapevines, the DF grapevines also received $\mathrm{Ca}, \mathrm{Mg}$ and trace elements. The fertiliser mix for the DF grapevines was adjusted nine times during the season, according to phenological stage. The stages were: bud break to $20 \mathrm{~cm}$ shoot length, $20 \mathrm{~cm}$ shoot length to the beginning of flowering, beginning to end of flowering, end of flowering to pea size berries, pea size berries to véraison, véraison to harvest, harvest to the end of March, the end of March to the end of leaf fall and, lastly, the end of leaf fall to bud break. For the LF and WF treatments, the fertilisers used were 1:0:1(14), phosphoric acid, urea and potassium chloride $(\mathrm{KCl})$. Fertiliser sources for the DF strategy were phosphoric acid, $\mathrm{KCl}, \mathrm{MgSO}_{4}, \mathrm{KNO}_{3}, \mathrm{Ca}\left(\mathrm{NO}_{3}\right)_{2}$ and Omnispoor $^{\circledR}$ (Table 4).

\section{Soil chemical analysis}

Chemical status in the 0 to $300 \mathrm{~mm}, 300 \mathrm{~mm}$ to $600 \mathrm{~mm}$ and $600 \mathrm{~mm}$ to $900 \mathrm{~mm}$ depth intervals was determined before the trial commenced in July 2001. Sampling was repeated at the end of the season in 2002/03 and on completion of the trial in $2003 / 04$. Samples were taken at 0 to $150 \mathrm{~mm}$, $150 \mathrm{~mm}$ to $300 \mathrm{~mm}$ and $300 \mathrm{~mm}$ to $600 \mathrm{~mm}$ depth intervals in the grapevine row beneath the dripper lines in all normal crop load treatments. Additional soil samples were taken at the end of the trial in the DF plots beneath the dripper, 150 $\mathrm{mm}$ and $300 \mathrm{~mm}$ away from the dripper, at 0 to $150 \mathrm{~mm}$, $150 \mathrm{~mm}$ to $300 \mathrm{~mm}$ and $300 \mathrm{~mm}$ to $600 \mathrm{~mm}$ depth intervals. Soil $\mathrm{pH}_{(\mathrm{KCl}}$, electrical conductivity of the saturated paste extract (EC $\mathrm{E}_{\mathrm{e}}$, P and $\mathrm{K}$ (Bray II), as well as exchangeable Ca and $\mathrm{Mg}$, were determined according to standard laboratory procedures as described by Lategan (2011).

\section{Plant and juice analyses}

Basal leaves opposite bunches were sampled in accordance with the protocol of Conradie (1994). Petioles were immediately separated from the leaf blade. Petioles and leaves were analysed for $\mathrm{N}, \mathrm{P}, \mathrm{K}, \mathrm{Ca}, \mathrm{Mg}$ and $\mathrm{Na}$. Juice was obtained by gently crushing berries sampled at harvest and squeezing the resultant juice through cheesecloth. To determine total $\mathrm{N}$, the juice was digested with selenic acid and concentrated sulphuric acid. Total $\mathrm{N}$ was then determined by means of a nitrogen analyser using methods described by Clesceri et al. (1998). To determine P, K, Ca and $\mathrm{Mg}$, juice samples were digested by adding concentrated

\section{TABLE 2}

Nutrient elements applied to grapevines that were fertigated at a low frequency and weekly frequencies during the 2002/03 and 2003/04 seasons near Paarl in the Berg River Valley region.

\begin{tabular}{lccc}
\hline Period & \multicolumn{3}{c}{ Element (kg/ha) } \\
\cline { 2 - 4 } & $\mathbf{N}$ & $\mathbf{P}$ & $\mathbf{K}$ \\
\hline Bud break to flowering & 36.2 & 7.5 & 35.2 \\
Fruit set to véraison & 36.2 & 7.5 & 35.2 \\
Post-harvest & 43.6 & 6.9 & 21.5 \\
\hline Total & 116.0 & 21.9 & 91.9 \\
\hline
\end{tabular}

nitric acid, allowing it to stand overnight and then adding perchloric acid. Following the nitric acid/perchloric acid digestion, the above-mentioned elements were determined using an inductively coupled plasma emission spectrometer (Liberty 200 ICP AES, Varian, Australia). Approximately 100 berries were deskinned; the skins were then dried and analysed for N, P, K, Ca and Mg. All plant and juice samples were analysed according to standard laboratory procedures described by Lategan (2011).

\section{Statistical analysis}

Treatment application began in the 2001/02 season, which was regarded as a pilot year. Data from the 2002/03 and 2003/04 seasons are presented in this article. Student's least significant difference (LSD) values were calculated to facilitate comparison between treatment means. Means that differed at $\mathrm{p} \leq 0.05$ were considered to be significantly different.

\section{RESULTS AND DISCUSSION \\ Soil chemical status}

Soil chemical conditions were within the norms for table grapes (Conradie \& Raath, unpublished data) before the field trial started in 2001/02 (Table 5). Where fertigation was applied according to the DF strategy, the soil directly beneath the drippers became too acidic for viticulture to a depth of $150 \mathrm{~mm}$, i.e. $\mathrm{pH}_{\mathrm{KCl}}<5.5$, after only three seasons (Table 6). This acidification accorded with earlier results (Komosa et al., 1999a; Treder, 2005). Furthermore, the pH beneath the dripper in the $150 \mathrm{~mm}$ to $300 \mathrm{~mm}$ depth interval was also lower than $150 \mathrm{~mm}$ away from the dripper (Fig. 1). At the beginning of the trial, the salinity hazard was low (Richards, 1954), i.e. $\mathrm{EC}_{\mathrm{e}}<0.25 \mathrm{dS} / \mathrm{m}$ (Table 5). Although the mean $\mathrm{EC}_{\mathrm{e}}$ of the $\mathrm{DF}$ treatments were comparable to that of lower frequency fertigation ( $\mathrm{LF}$ and WF), a notable amount of salts accumulated on the perimeter of the small wetted soil volumes after only three seasons (Fig. 2). Although the salt content on the perimeter had a medium salt hazard, i.e. $0.25 \mathrm{dS} / \mathrm{m}$ to $0.75 \mathrm{dS} / \mathrm{m}$ (Richards, 1954), it could become problematic in the long run. The observed salt distribution pattern seemed to have been a combination of lateral flow away from the dripper and upward flow along the perimeter due to evaporation at the soil surface. Komosa et al. (1999a) also reported a decrease in $\mathrm{EC}_{\mathrm{e}}$ under drippers, but higher values $40 \mathrm{~cm}$ from drippers. The highest root density, and most intensive uptake of nutrients, usually occur in the wetted volume under drippers (Komosa et al., 1999a). Hence, the high root densities in the small wetted volumes (Myburgh \& Howell, 2012) could have contributed to the observed salt distribution. The LF and WF treatments did not seem to have a serious effect on the soil chemical status beneath the dripper lines in the 0 to $300 \mathrm{~mm}$ and $300 \mathrm{~mm}$ to $600 \mathrm{~mm}$ depth intervals during the following two seasons (Table 6)

Acidification and the accumulation of salts at the edges of the wetted volume are common results of drip irrigation, particularly on sandy soils. This can be difficult to alleviate and should be managed by sampling regularly in order to adjust the fertiliser composition or apply lime where necessary. In the long term, substantial salt accumulation 

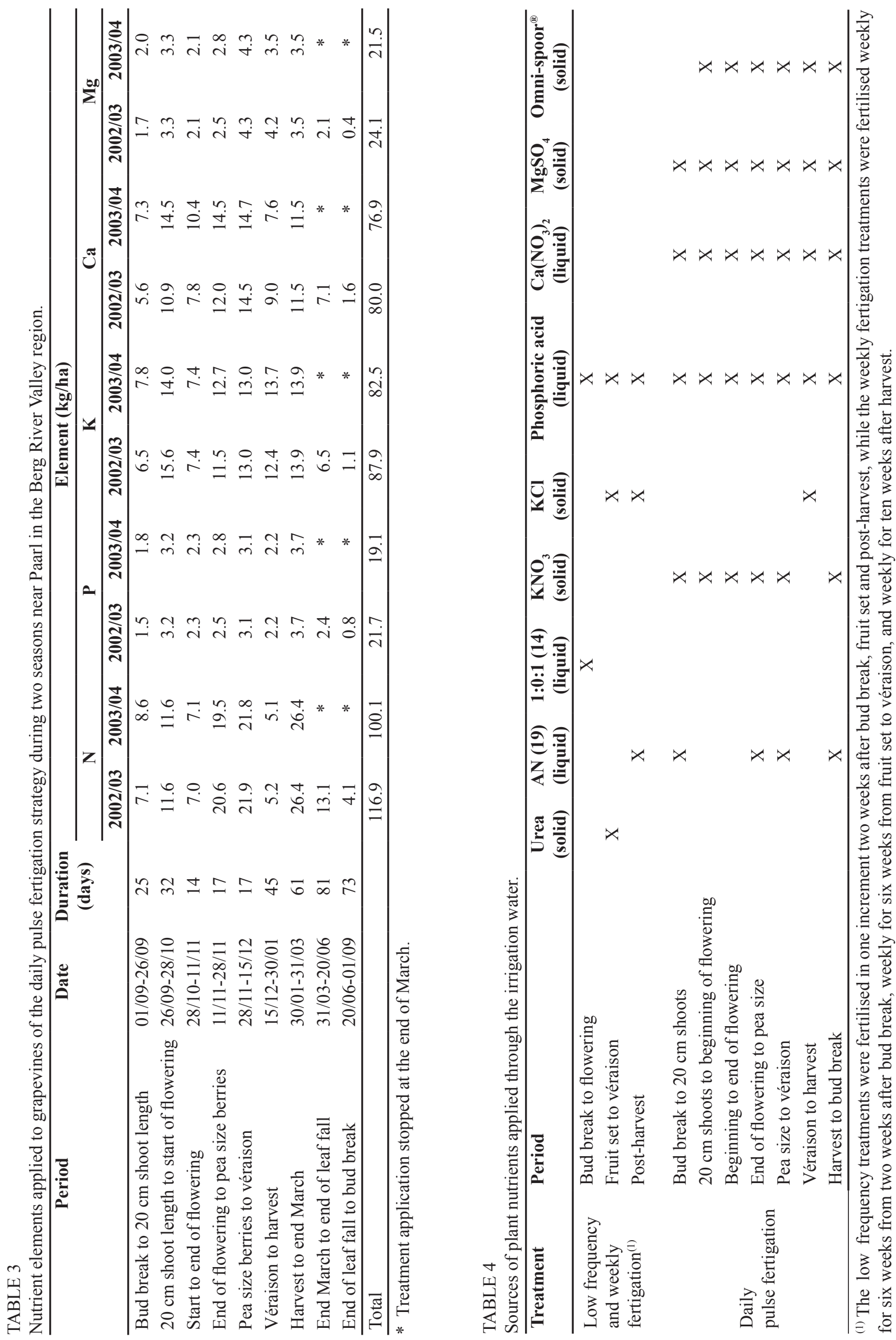
around the relatively small root systems may cause problems if some of the salts are suddenly redistributed back into the root systems when it rains. The formation of accumulation zones as a result of fertigation or drip irrigation indicates a lateral movement of minerals that is closely related to the distribution of water under the dripper (Komosa et al., 1999b). It must be noted that these results do not rule out the possibility that localised acidification and/or salt accumulation had also occurred to some extent in the LF and WF treatments. The accumulation of salts around the wetted zone is a particular cause for concern. This study was conducted in a winter rainfall area and, in all probability, these salts were leached from the profile by the winter rains.

\section{Grapevine nutritional status}

\section{Leaves}

Element concentrations in the petioles and leaf blades for all treatments were within the current norms for table grapes
(Conradie, 1994) and were comparable in both seasons (Tables $7 \& 8$ ). Although the irrigation intervals and amounts were increased in 2003/04, petiole and leaf blade element contents only tended to be higher compared with the 2002/03 season.

Grapevines bearing a normal crop load fertigated at a low frequency had higher petiole $\mathrm{N}$ than $\mathrm{LF}_{\mathrm{H}}$ and the two WF treatments. However, their petiole $\mathrm{N}$ contents were similar to that of DF grapevines, regardless of crop load. There are two peak periods of $\mathrm{N}$ absorption by grapevines, namely from approximately four weeks after bud break to véraison and from harvest until leaf fall (Conradie, 1980). Therefore, it appears that the uptake of $\mathrm{N}$ by the Dan-benHannah grapevines was promoted by the LF strategy. In addition, daily applications of $\mathrm{N}$ also promoted $\mathrm{N}$ uptake. In contrast, weekly fertigation of Concord grapevines from bud break to véraison increased petiole $\mathrm{N}$ when compared

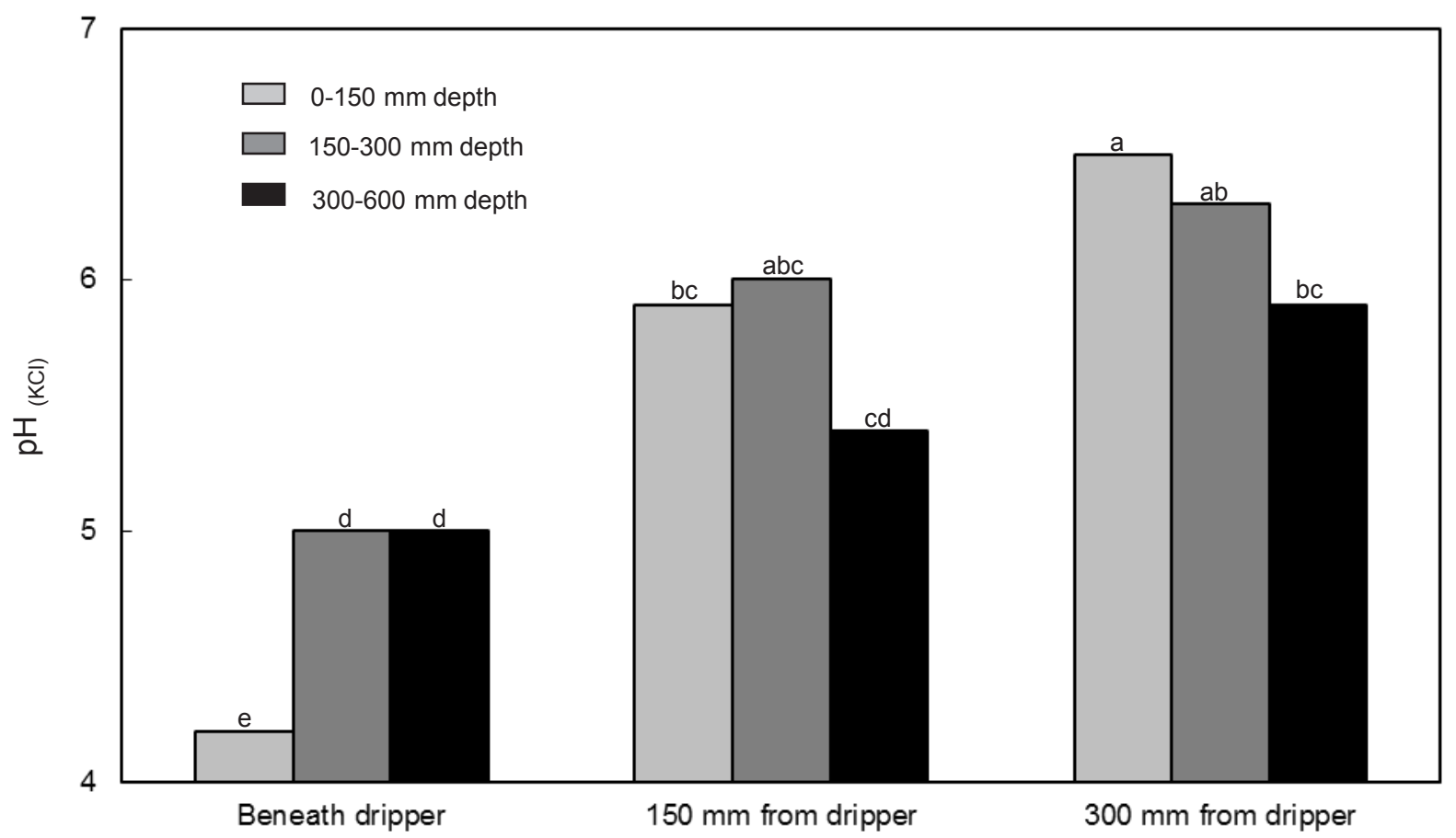

FIGURE 1

Effect of daily pulse fertigation on $\mathrm{pH}_{(\mathrm{KCl})}$ beneath and around drippers determined in March 2004, i.e. after three seasons.

TABLE 5

Mean soil $\mathrm{pH}_{(\mathrm{KCl})}$, electrical conductivity of the saturated paste extract $\left(\mathrm{EC}_{\mathrm{e}}\right)$, phosphorus and potassium, as well as exchangeable calcium and magnesium, determined during July 2001 before the field trial commenced.

\begin{tabular}{lccc}
\hline Variable & \multicolumn{3}{c}{ Soil depth interval } \\
\cline { 2 - 4 } & $\mathbf{0}$ to $\mathbf{3 0 0} \mathbf{~ m m}$ & $\mathbf{3 0 0} \mathbf{~ m m}$ to $\mathbf{6 0 0} \mathbf{~ m m}$ & $\mathbf{6 0 0} \mathbf{~ m m}$ to $\mathbf{9 0 0} \mathbf{~ m m}$ \\
\hline $\mathrm{pH}_{(\mathrm{KCl})}$ & $6.2 \pm 0.4$ & $5.1 \pm 0.4$ & $4.8 \pm 0.4$ \\
$\mathrm{EC}_{\mathrm{e}}(\mathrm{dS} / \mathrm{m})$ & $0.09 \pm 0.02$ & $0.08 \pm 0.03$ & $0.11 \pm 0.04$ \\
$\mathrm{P}(\mathrm{mg} / \mathrm{kg})$ & $71 \pm 24$ & $24 \pm 8$ & $19 \pm 14$ \\
$\mathrm{~K}(\mathrm{mg} / \mathrm{kg})$ & $63 \pm 26$ & $35 \pm 19$ & $43 \pm 22$ \\
Exchangeable Ca $(\mathrm{cmol} / \mathrm{kg})$ & $3.25 \pm 0.97$ & $1.75 \pm 0.63$ & $1.89 \pm 0.52$ \\
Exchangeable $\mathrm{Mg}(\mathrm{cmol} / \mathrm{kg})$ & $0.57 \pm 0.15$ & $0.36 \pm 0.12$ & $0.40 \pm 0.13$ \\
\hline
\end{tabular}




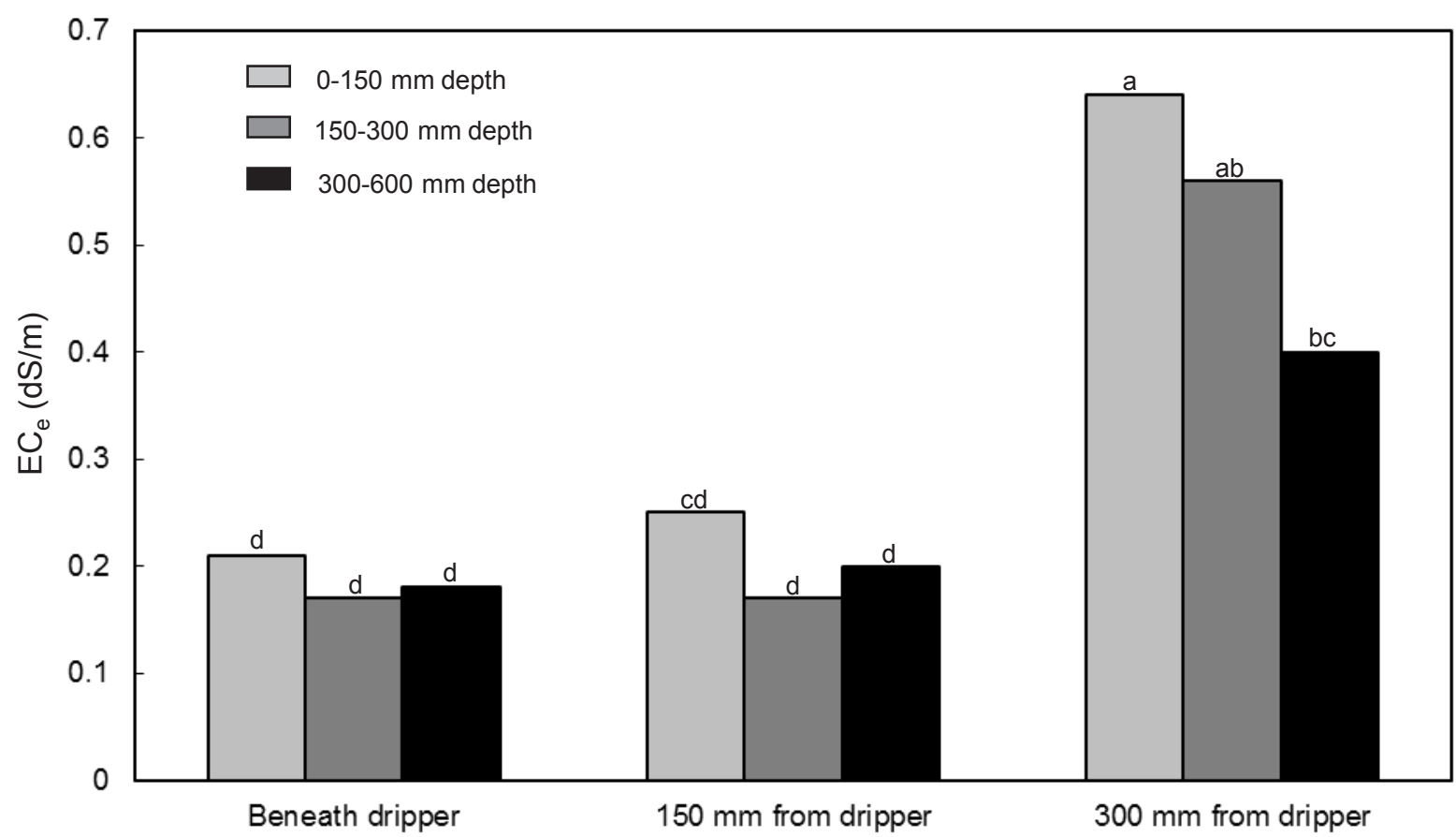

FIGURE 2

Effect of daily pulse fertigation on electrical conductivity $\left(\mathrm{EC}_{\mathrm{e}}\right)$ beneath and around drippers, determined in March 2004, i.e. after three seasons.

TABLE 6

Effect of low frequency (LF), weekly (WF) and daily pulse (DF) fertigation on soil $\mathrm{pH}_{(\mathrm{KC})}$, electrical conductivity of the saturated paste extract $\left(\mathrm{EC}_{\mathrm{e}}\right)$, phosphorus and potassium, as well as exchangeable calcium and magnesium, determined at the end of the 2002/03 and 2003/04 seasons, respectively, near Paarl in the Berg River Valley region.

\begin{tabular}{|c|c|c|c|c|c|c|c|c|c|}
\hline \multirow[t]{2}{*}{ Season } & \multicolumn{3}{|c|}{$0 \mathrm{~mm}$ to $150 \mathrm{~mm}$} & \multicolumn{3}{|c|}{$150 \mathrm{~mm}$ to $300 \mathrm{~mm}$} & \multicolumn{3}{|c|}{$300 \mathrm{~mm}$ to $600 \mathrm{~mm}$} \\
\hline & $\mathbf{L} \mathbf{F}^{(\mathbf{1})}$ & WF & DF & LF & WF & DF & $\mathbf{L F}$ & WF & DF \\
\hline & \multicolumn{9}{|c|}{$\mathbf{p H}_{(\mathrm{KCl})}$} \\
\hline $2002 / 03$ & $6.1 \mathrm{ab}^{(2)}$ & $6.6 \mathrm{a}$ & $5.5 \mathrm{bcd}$ & $5.1 \mathrm{~cd}$ & $5.5 \mathrm{bcd}$ & $5.9 \mathrm{~b}$ & $5.0 \mathrm{~d}$ & $5.2 \mathrm{~cd}$ & $5.6 \mathrm{~b}$ \\
\hline \multirow[t]{2}{*}{$2003 / 04$} & $5.7 \mathrm{ab}$ & $6.2 \mathrm{a}$ & $4.2 \mathrm{c}$ & $5.0 \mathrm{~b}$ & $5.6 \mathrm{ab}$ & $5.0 \mathrm{~b}$ & $5.0 \mathrm{~b}$ & $5.5 \mathrm{ab}$ & $5.0 \mathrm{~b}$ \\
\hline & \multicolumn{9}{|c|}{$E C_{e}(d S / m)$} \\
\hline $2002 / 03$ & $0.17 \mathrm{bc}$ & $0.13 \mathrm{bc}$ & $0.26 \mathrm{a}$ & $0.16 \mathrm{bc}$ & $0.11 \mathrm{c}$ & $0.17 \mathrm{abc}$ & $0.21 \mathrm{ab}$ & $0.16 \mathrm{bc}$ & $0.11 \mathrm{c}$ \\
\hline \multirow[t]{2}{*}{$2003 / 04$} & $0.14 \mathrm{c}$ & $0.35 \mathrm{a}$ & $0.21 \mathrm{bc}$ & $0.17 \mathrm{bc}$ & $0.24 \mathrm{~b}$ & $0.17 \mathrm{bc}$ & $0.21 \mathrm{bc}$ & $0.21 \mathrm{bc}$ & $0.18 \mathrm{bc}$ \\
\hline & \multicolumn{9}{|c|}{$P(\mathrm{mg} / \mathrm{kg})$} \\
\hline $2002 / 03$ & $117 \mathrm{ab}$ & $148 \mathrm{a}$ & 84 bc & $52 \mathrm{cde}$ & $65 \mathrm{cde}$ & 72 bcd & 39 cde & $36 \mathrm{de}$ & $23 \mathrm{e}$ \\
\hline \multirow[t]{2}{*}{$2003 / 04$} & $98 \mathrm{~b}$ & $134 \mathrm{a}$ & $64 \mathrm{c}$ & $89 \mathrm{~b}$ & $55 \mathrm{c}$ & $50 \mathrm{~cd}$ & $57 \mathrm{c}$ & $36 \mathrm{de}$ & $22 \mathrm{e}$ \\
\hline & \multicolumn{9}{|c|}{ K (mg/kg) } \\
\hline $2002 / 03$ & $61 \mathrm{a}$ & $65 \mathrm{a}$ & $92 \mathrm{a}$ & $52 \mathrm{a}$ & $57 \mathrm{a}$ & $68 \mathrm{a}$ & $85 \mathrm{a}$ & $75 \mathrm{a}$ & $56 a$ \\
\hline \multirow[t]{2}{*}{$2003 / 04$} & $79 \mathrm{a}$ & $78 \mathrm{a}$ & $58 \mathrm{c}$ & $73 \mathrm{ab}$ & $64 \mathrm{bc}$ & $56 \mathrm{c}$ & $84 \mathrm{a}$ & $60 \mathrm{c}$ & $53 \mathrm{c}$ \\
\hline & \multicolumn{9}{|c|}{ Exchangeable Ca (cmol/kg) } \\
\hline $2002 / 03$ & $3.80 \mathrm{~b}$ & $5.48 \mathrm{a}$ & $3.66 \mathrm{bc}$ & $1.72 \mathrm{~d}$ & $2.33 \mathrm{~cd}$ & $2.58 \mathrm{bcd}$ & $1.61 \mathrm{~d}$ & $1.56 \mathrm{~d}$ & $1.28 \mathrm{~d}$ \\
\hline \multirow[t]{2}{*}{$2003 / 04$} & $3.80 \mathrm{bc}$ & $5.85 \mathrm{a}$ & $2.83 \mathrm{~cd}$ & $2.57 \mathrm{de}$ & $4.28 \mathrm{~b}$ & $2.72 \mathrm{cde}$ & $2.00 \mathrm{de}$ & $2.70 \mathrm{cde}$ & $1.55 \mathrm{e}$ \\
\hline & \multicolumn{9}{|c|}{ Exchangeable Mg (cmol/kg) } \\
\hline $2002 / 03$ & $0.92 \mathrm{ab}$ & $0.87 \mathrm{ab}$ & $1.08 \mathrm{a}$ & $0.30 \mathrm{~d}$ & $0.34 \mathrm{~cd}$ & $0.69 \mathrm{bc}$ & $0.30 \mathrm{~d}$ & $0.33 \mathrm{~cd}$ & $0.32 \mathrm{~cd}$ \\
\hline $2003 / 04$ & $0.77 \mathrm{ab}$ & $0.85 \mathrm{a}$ & $0.68 \mathrm{abc}$ & $0.41 \mathrm{de}$ & $0.59 \mathrm{bcd}$ & $0.52 \mathrm{cde}$ & $0.33 \mathrm{e}$ & $0.38 \mathrm{de}$ & $0.35 \mathrm{e}$ \\
\hline
\end{tabular}

${ }^{(1)}$ Refer to Table 1 for more details of the treatments.

(2) Values designated by the same letter within each row do not differ significantly $(\mathrm{p} \leq 0.05)$. 
to grapevines that received the same amount of fertiliser applied in two applications (Reynolds et al., 2005). In the 2003/04 season, $\mathrm{DF}_{\mathrm{N}}$ grapevines also had more petiole $\mathrm{N}$ than $\mathrm{WF}_{\mathrm{N}}$ grapevines (Table 7). In general, petioles were more responsive to fertigation strategies than leaf blades. Under the conditions of the trial, the LF strategy was as effective for the accumulation of $\mathrm{N}$ in petioles as the DF strategy for grapevines bearing a normal crop load. However, for grapevines bearing a high crop load, the DF strategy was the most effective for the accumulation of $\mathrm{N}$ in the petioles. In both seasons, petiole $\mathrm{N}$ in the LF grapevines showed a significant response to crop load. There were no significant differences in the leaf blade $\mathrm{N}$ contents between treatments in 2002/03 (Table 8). In 2003/04, leaf blade $\mathrm{N}$ tended to be higher in the $\mathrm{DF}_{\mathrm{N}}$ grapevines than in the $\mathrm{LF}_{\mathrm{N}}$ and $\mathrm{WF}_{\mathrm{N}}$ grapevines. This suggests that smaller, more frequent applications improved $\mathrm{N}$ uptake. In addition, the growth of roots in the wetted volumes of the DF treatments probably also promoted the uptake of $\mathrm{N}$. In 2003/04, the $\mathrm{DF}_{\mathrm{N}}$ grapevines had higher leaf blade $\mathrm{N}$ than the $\mathrm{DF}_{\mathrm{H}}$ grapevines.
A similar trend was observed for the two other fertigation strategies.

The DF strategy promoted the uptake of $\mathrm{P}$ by the petioles (Table 7). Furthermore, grapevines bearing a higher crop load tended to have less petiole P. Although it has been reported that split applications of $\mathrm{N}$ by hand reduced the petiole $\mathrm{P}$ of Heroldrebe grapevines (Conradie, 2001), there were no differences in petiole $\mathrm{P}$ between the LF and WF grapevines. According to Klein et al. (2000), at low intensities of $\mathrm{P}$ nutrition, leaf blade $\mathrm{P}$ is higher than petiole $\mathrm{P}$, whereas petiole $\mathrm{P}$ is higher than leaf blade $\mathrm{P}$ for high intensities of $\mathrm{P}$ nutrition. Leaf blades have priority for $\mathrm{P}$, but there is a limit to nutrient accumulation by the leaf blade. In both seasons, leaf blade $\mathrm{P}$ in the $\mathrm{DF}_{\mathrm{N}}$ grapevines was higher than in the LF and WF grapevines, irrespective of crop load (Table 8). Furthermore, leaf blade $\mathrm{P}$ in the $\mathrm{DF}_{\mathrm{H}}$ grapevines was also higher than in the $\mathrm{LF}_{\mathrm{H}}, \mathrm{WF}_{\mathrm{N}}$ and $\mathrm{WF}_{\mathrm{H}}$ grapevines. As in the case of the petioles, leaf blade $\mathrm{P}$ was affected by crop load (Table 8 ). These results strongly indicate that daily applications of fertilisers improve $\mathrm{P}$ uptake by grapevines and that the grapevine is responsive

\section{TABLE 7}

Effect of low frequency (LF), weekly (WF) and daily pulse (DF) fertigation as well as normal (N) and high (H) crop loads on leaf petiole element contents of Dan-ben-Hannah grapevines determined at harvest during the 2002/03 and 2003/04 seasons near Paarl in the Berg River Valley region.

\begin{tabular}{|c|c|c|c|c|c|c|}
\hline \multirow[t]{3}{*}{ Season } & \multicolumn{6}{|c|}{ Fertigation-crop load treatments } \\
\hline & $\mathbf{L F}_{\mathrm{N}}^{(1)}$ & $\mathbf{L F}_{\mathrm{H}}$ & $\mathbf{W F}_{\mathrm{N}}$ & $\mathbf{W F}_{\mathrm{H}}$ & $\mathbf{D F}_{\mathrm{N}}$ & $\mathbf{D F}_{\mathrm{H}}$ \\
\hline & \multicolumn{6}{|c|}{$\mathbf{N}(\%)^{(2)}$} \\
\hline $2002 / 03$ & $0.86 \mathrm{a}^{(3)}$ & $0.72 \mathrm{~b}$ & $0.70 \mathrm{~b}$ & $0.72 \mathrm{~b}$ & $0.78 \mathrm{ab}$ & $0.77 \mathrm{ab}$ \\
\hline \multirow[t]{2}{*}{$2003 / 04$} & $0.99 \mathrm{a}$ & $0.83 \mathrm{c}$ & $0.83 \mathrm{c}$ & $0.84 \mathrm{bc}$ & $0.93 \mathrm{ab}$ & $0.92 \mathrm{ab}$ \\
\hline & \multicolumn{6}{|c|}{$\mathbf{P}(\%)^{(4)}$} \\
\hline $2002 / 03$ & $0.26 \mathrm{~b}$ & $0.23 \mathrm{~b}$ & $0.26 \mathrm{~b}$ & $0.22 \mathrm{~b}$ & $0.46 \mathrm{a}$ & $0.43 \mathrm{a}$ \\
\hline \multirow[t]{2}{*}{$2003 / 04$} & $0.30 \mathrm{~b}$ & $0.24 \mathrm{~b}$ & $0.29 \mathrm{~b}$ & $0.24 \mathrm{~b}$ & $0.53 \mathrm{a}$ & $0.49 \mathrm{a}$ \\
\hline & \multicolumn{6}{|c|}{$K(\%)^{(5)}$} \\
\hline $2002 / 03$ & $2.38 \mathrm{a}$ & $2.27 \mathrm{a}$ & $2.37 \mathrm{a}$ & $2.30 \mathrm{a}$ & $2.43 \mathrm{a}$ & $2.31 \mathrm{a}$ \\
\hline \multirow[t]{2}{*}{$2003 / 04$} & $2.76 \mathrm{a}$ & $2.41 \mathrm{a}$ & $2.60 \mathrm{a}$ & $2.31 \mathrm{a}$ & $2.76 \mathrm{a}$ & $2.60 \mathrm{a}$ \\
\hline & \multicolumn{6}{|c|}{$\mathrm{Ca}(\%)^{(6)}$} \\
\hline $2002 / 03$ & $1.41 \mathrm{a}$ & $1.40 \mathrm{a}$ & $1.50 \mathrm{a}$ & $1.47 \mathrm{a}$ & $1.42 \mathrm{a}$ & $1.53 \mathrm{a}$ \\
\hline \multirow[t]{2}{*}{$2003 / 04$} & $1.41 \mathrm{a}$ & $1.46 \mathrm{a}$ & $1.54 \mathrm{a}$ & $1.47 \mathrm{a}$ & $1.51 \mathrm{a}$ & $1.55 \mathrm{a}$ \\
\hline & \multicolumn{6}{|c|}{$\operatorname{Mg}(\%)^{(7)}$} \\
\hline $2002 / 03$ & $0.58 \mathrm{a}$ & $0.60 \mathrm{a}$ & $0.64 \mathrm{a}$ & $0.55 \mathrm{a}$ & $0.57 \mathrm{a}$ & $0.55 \mathrm{a}$ \\
\hline \multirow[t]{2}{*}{ 2003/04 } & $0.58 \mathrm{a}$ & $0.66 \mathrm{a}$ & $0.67 \mathrm{a}$ & $0.60 \mathrm{a}$ & $0.63 \mathrm{a}$ & $0.61 \mathrm{a}$ \\
\hline & \multicolumn{6}{|c|}{$\mathrm{Na}(\mathrm{mg} / \mathrm{kg})^{(8)}$} \\
\hline $2002 / 03$ & $556 \mathrm{~b}$ & $643 \mathrm{a}$ & $679 a$ & $646 \mathrm{a}$ & $634 \mathrm{ab}$ & $652 \mathrm{a}$ \\
\hline 2003/04 & $586 \mathrm{a}$ & $646 \mathrm{a}$ & $641 \mathrm{a}$ & $658 \mathrm{a}$ & $658 \mathrm{a}$ & $684 \mathrm{a}$ \\
\hline
\end{tabular}

(1) Refer to Table 1 for more details of the treatments.

(2) Adequate range for petiole $\mathrm{N}$ ranges from $0.60 \%$ to $0.98 \%$ (Conradie, 1994).

(3) Values designated by the same letter within each row do not differ significantly $(\mathrm{p} \leq 0.05)$.

(4) Adequate range for petiole $P$ ranges from $0.11 \%$ to $0.62 \%$ (Conradie, 1994).

(5) Adequate range for petiole $\mathrm{K}$ ranges from $1.00 \%$ to $2.90 \%$ (Conradie, 1994).

(6) Adequate range for petiole Ca ranges from $0.60 \%$ to $1.40 \%$ (Conradie, 1994 ).

(7) Adequate range for petiole $\mathrm{Mg}$ ranges from $0.25 \%$ to $0.80 \%$ (Conradie, 1994).

${ }^{(8)}$ Maximum level for petiole $\mathrm{Na}$ is $0.50 \%$ (Conradie, 1994). 
with respect to $\mathrm{P}$ applied, as previously reported by Klein et al. (2000). Furthermore, a higher concentration of roots in a small soil volume locally increased the root-to-soil ratio, thereby promoting the ability of the roots to take up nutrients (Falivene, 2005). However, the improved uptake of $\mathrm{P}$ by the DF grapevines may have implications for $\mathrm{K}$ uptake, since there is $\mathrm{P} / \mathrm{K}$ antagonism (Conradie \& Saayman, 1989).

In contrast to petiole $\mathrm{N}$ and $\mathrm{P}$, there were no differences in petiole $\mathrm{K}$, and the only consistent trend with respect to petiole K was the effect of crop load (Table 7). Although Christensen et al. (1991) reported higher K levels in petioles at flowering for grapevines that received a single application of $\mathrm{K}_{2} \mathrm{SO}_{4}$ in comparison to grapevines that received the same amount of fertiliser in eight increments, by véraison the $\mathrm{K}$ levels in the petioles of grapevines fertilised over eight weeks were higher than in grapevines receiving the once-off application. In subsequent years of the study, there were no differences in petiole $\mathrm{K}$ with respect to rate of application. Reynolds et al. (2005) also reported that the uptake of K by Concord grapevines was not enhanced by either irrigation or fertigation. In both seasons, the $\mathrm{WF}_{\mathrm{N}}$ grapevines had lower leaf blade $\mathrm{K}$ than compared than the $\mathrm{DF}_{\mathrm{N}}$ and $\mathrm{LF}_{\mathrm{N}}$ grapevines (Table 8). The period of peak grapevine absorption of $\mathrm{K}$ is from three weeks after bud burst until four to five weeks after harvest (Conradie, 1981). In 2002/03, the leaf blade $\mathrm{K}$ of the $\mathrm{LF}_{\mathrm{N}}$ and $\mathrm{DF}_{\mathrm{N}}$ grapevines tended to be higher than that of the $\mathrm{LF}_{\mathrm{H}}$ and $\mathrm{DF}_{\mathrm{H}}$ grapevines (Table 8). This crop load effect was significant in 2003/04 (Table 8). There were no treatment differences between grapevines bearing high crop loads and this implies that the $\mathrm{K}$ content in the soil was generally sufficient to supply the grapevine requirements.

Petiole $\mathrm{Na}$ in the LF grapevines was lower than for all the other treatments, with the exception of $\mathrm{DF}_{\mathrm{N}}$ in 2002/03 (Table 7). Furthermore, petiole $\mathrm{Na}$ of the $\mathrm{LF}_{\mathrm{N}}$ grapevines was lower than that of the $\mathrm{LF}_{\mathrm{H}}$ grapevines. There were no crop load differences for $\mathrm{Na}$ in the petioles of the two other treatments. A similar trend was observed in 2003/04. There were no significant treatment related differences in leaf blade $\mathrm{Ca}$ and $\mathrm{Na}$ contents in either of the two seasons. In the 2002/03 season, leaf blade Mg of the DF grapevines was

\section{TABLE 8}

Effect of low frequency (LF), weekly (WF) and daily pulse (DF) fertigation, as well as normal (N) and high (H) crop loads, on leaf blade element contents of Dan-ben-Hannah grapevines determined at harvest during the 2002/03 and 2003/04 seasons near Paarl in the Berg River Valley region.

\begin{tabular}{|c|c|c|c|c|c|c|}
\hline \multirow[t]{3}{*}{ Season } & \multicolumn{6}{|c|}{ Fertigation-crop load treatment ${ }^{(1)}$} \\
\hline & $\mathbf{L F}_{\mathrm{N}}$ & $\mathbf{L F}_{\mathbf{H}}$ & $\mathbf{W F}_{\mathrm{N}}$ & $\mathbf{W F}_{\mathrm{H}}$ & $\mathrm{DF}_{\mathrm{N}}$ & $\mathrm{DF}_{\mathrm{H}}$ \\
\hline & \multicolumn{6}{|c|}{$\mathbf{N}(\%)^{(2)}$} \\
\hline $2002 / 03$ & $2.11 \mathrm{a}^{(3)}$ & $2.02 \mathrm{a}$ & $2.10 \mathrm{a}$ & $2.07 \mathrm{a}$ & $2.11 \mathrm{a}$ & $2.07 \mathrm{a}$ \\
\hline \multirow[t]{2}{*}{$2003 / 04$} & $2.35 \mathrm{abc}$ & $2.26 \mathrm{c}$ & $2.38 \mathrm{ab}$ & $2.28 \mathrm{bc}$ & $2.42 \mathrm{a}$ & $2.29 \mathrm{bc}$ \\
\hline & \multicolumn{6}{|c|}{$\mathbf{P}(\%)^{(4)}$} \\
\hline $2002 / 03$ & $0.19 \mathrm{bc}$ & $0.17 \mathrm{c}$ & $0.18 \mathrm{c}$ & $0.17 \mathrm{c}$ & $0.23 \mathrm{a}$ & $0.21 \mathrm{ab}$ \\
\hline \multirow[t]{2}{*}{$2003 / 04$} & $0.20 \mathrm{bc}$ & $0.17 \mathrm{c}$ & $0.19 \mathrm{c}$ & $0.17 \mathrm{c}$ & $0.26 \mathrm{a}$ & $0.23 \mathrm{ab}$ \\
\hline & \multicolumn{6}{|c|}{$\mathbf{K}(\%)^{(5)}$} \\
\hline $2002 / 03$ & $0.93 \mathrm{a}$ & $0.84 \mathrm{ab}$ & $0.83 \mathrm{~b}$ & $0.85 \mathrm{ab}$ & $0.92 \mathrm{a}$ & $0.87 \mathrm{ab}$ \\
\hline \multirow[t]{2}{*}{$2003 / 04$} & $0.99 \mathrm{a}$ & $0.87 \mathrm{~b}$ & $0.90 \mathrm{~b}$ & $0.85 \mathrm{~b}$ & $1.00 \mathrm{a}$ & $0.89 \mathrm{~b}$ \\
\hline & \multicolumn{6}{|c|}{$\operatorname{Ca}(\%)^{(6)}$} \\
\hline $2002 / 03$ & $2.08 \mathrm{a}$ & $2.06 \mathrm{a}$ & $2.11 \mathrm{a}$ & $2.06 \mathrm{a}$ & $2.04 \mathrm{a}$ & $2.16 \mathrm{a}$ \\
\hline \multirow[t]{2}{*}{$2003 / 04$} & $2.22 \mathrm{a}$ & $2.18 \mathrm{a}$ & $2.31 \mathrm{a}$ & $2.10 \mathrm{a}$ & $2.12 \mathrm{a}$ & $2.25 \mathrm{a}$ \\
\hline & \multicolumn{6}{|c|}{$\operatorname{Mg}(\%)^{(7)}$} \\
\hline $2002 / 03$ & $0.46 \mathrm{a}$ & $0.46 \mathrm{a}$ & $0.43 \mathrm{abc}$ & $0.42 \mathrm{abc}$ & $0.41 \mathrm{bc}$ & $0.40 \mathrm{c}$ \\
\hline \multirow[t]{2}{*}{$2003 / 04$} & $0.53 \mathrm{a}$ & $0.49 \mathrm{a}$ & $0.49 \mathrm{a}$ & $0.46 \mathrm{a}$ & $0.48 \mathrm{a}$ & $0.47 \mathrm{a}$ \\
\hline & \multicolumn{6}{|c|}{$\mathrm{Na}(\mathbf{m g} / \mathbf{k g})^{(8)}$} \\
\hline $2002 / 03$ & $551 \mathrm{a}$ & $573 \mathrm{a}$ & $543 \mathrm{a}$ & $655 \mathrm{a}$ & $539 \mathrm{a}$ & $522 \mathrm{a}$ \\
\hline $2003 / 04$ & $564 \mathrm{a}$ & $580 \mathrm{a}$ & $532 \mathrm{a}$ & $585 \mathrm{a}$ & $559 \mathrm{a}$ & $541 \mathrm{a}$ \\
\hline
\end{tabular}

(1) Refer to Table 1 for more details of the treatments.

(2) Adequate range for leaf blade $\mathrm{N}$ ranges from $1.60 \%$ to $2.70 \%$ (Conradie, 1994).

(3) Values designated by the same letter within each row do not differ significantly $(\mathrm{p} \leq 0.05)$.

(4) Adequate range for leaf blade $\mathrm{P}$ ranges from $0.14 \%$ to $0.55 \%$ (Conradie, 1994).

(5) Adequate range for leaf blade $\mathrm{K}$ ranges from $0.65 \%$ to $1.30 \%$ (Conradie, 1994).

(6) Adequate range for leaf blade Ca ranges from $1.20 \%$ to $2.20 \%$ (Conradie, 1994).

(7) Adequate range for leaf blade $\mathrm{Mg}$ ranges from $0.16 \%$ to $0.55 \%$ (Conradie, 1994).

${ }^{(8)}$ Maximum level for leaf blade $\mathrm{Na}$ is $0.25 \%$ (Conradie, 1994). 
lower than that of the LF grapevines, irrespective of crop load. Although not significant, the same trend occurred in 2003/04. This suggests that daily applications of nutrients exacerbated a K-induced suppression of $\mathrm{Mg}$ absorption (Saayman, 1981). In spite of these differences, all elements appeared to be adequately supplied in all the treatments (Conradie, 1994).

\section{Juice and berry skins}

All grapevines bearing high crop loads tended to have lower juice $\mathrm{N}$ at harvest compared with those bearing a normal crop load (Table 9). This is due to an increased sink, namely more berries in the high crop load, which require nutrients, resulting in a dilution effect. A similar trend occurred in 2003/04. In both seasons, juice $\mathrm{N}$ was higher in the $\mathrm{DF}_{\mathrm{N}}$ grapevines than in the $\mathrm{LF}_{\mathrm{H}}$ grapevines. Furthermore, in 2003/04, juice $\mathrm{N}$ was higher in the $\mathrm{DF}_{\mathrm{N}}$ grapevines than in the $\mathrm{LF}_{\mathrm{N}}, \mathrm{LF}_{\mathrm{H}}$ and $\mathrm{WF}_{\mathrm{H}}$ ones. In spite of the petiole $\mathrm{N}$ response to the treatments, the fertigation strategies did not have a negative effect on the accumulation of $\mathrm{N}$ in the berries. This suggests that the $\mathrm{N}$ content of the soil and leaves was sufficient to supply $\mathrm{N}$ to the bunches. The juice $\mathrm{N}$ levels were similar to the levels reported for Sunred Seedless and Muscat Supreme table grapes growing in the Hex River Valley region of South Africa (Myburgh \& Howell, 2007).

In both seasons, the juice P content of the DF grapevines was higher than that of the LF and WF grapevines, irrespective of crop load (Table 9). This supports the trends observed for the petioles and leaf blades. In general, the juice $P$ of grapevines bearing a normal crop load tended to be higher than for those with a high crop load. The juice $P$ of DF juice was slightly higher than that reported for Sunred
Seedless and Muscat Supreme (Myburgh \& Howell, 2007).

The results for $\mathrm{K}$ in the juice were inconsistent with respect to fertigation strategy and crop load (Table 9). This is in accordance with the findings of Conradie (2001), who showed that there were no differences in juice $\mathrm{K}$ between conventionally split and single applications of $\mathrm{N}$. The $\mathrm{K}$ content in Muscat Supreme and Sunred Seedless juice ranged from $913 \mathrm{mg} / \mathrm{L}$ to $1207 \mathrm{mg} / \mathrm{L}$ (Myburgh \& Howell, 2007), which is somewhat lower than was observed for Danben-Hannah in the current study. There were no differences in juice Ca content in 2002/03 (Table 9), indicating that the $\mathrm{Ca}$ applied to the DF grapevines did not reflect in the juice. In 2003/04, $\mathrm{LF}_{\mathrm{N}}$ had more juice $\mathrm{Ca}$ than $\mathrm{WF}_{\mathrm{N}}, \mathrm{WF}_{\mathrm{H}}$ and $\mathrm{DF}_{\mathrm{H}}$. In fact, the juice $\mathrm{Ca}$ of the DF grapevines tended to be lower than that of the other treatments.

In 2002/03, the juice $\mathrm{Mg}$ of $\mathrm{LF}_{\mathrm{N}}$ tended to be more than that of $\mathrm{DF}_{\mathrm{N}}$ (Table 9). In the 2003/04 season, the juice $\mathrm{Mg}$ content of the $\mathrm{LF}_{\mathrm{N}}$ grapevines was higher than in all the other treatments. Although fertigated Bukettraube grapevines had less $\mathrm{Mg}$ in both leaf blades and petioles when compared with conventionally fertilised grapevines, neither fertigation nor conventional fertilisation affected the concentrations of the mineral ions in the grape juice (Conradie \& Myburgh, 2000).

The element contents of the juice were comparable in the 2002/03 and 2003/04 seasons, although the irrigation intervals and amounts were increased.

Although the petiole $\mathrm{N}$ content of the LF grapevines was higher than that of the WF grapevines, this did not reflect in differences in berry skin N content (Table 10). The berry skins of the DF grapevines contained more $\mathrm{N}$ than those of the LF and WF treatments in both seasons (Table 10). However, in 2003/04, the berry skin $\mathrm{N}$ content of the $\mathrm{DF}_{\mathrm{H}}$ grapevines was

TABLE 9

Effect of low frequency (LF), weekly (WF) and daily pulse (DF) fertigation, as well as normal (N) and high (H) crop loads, on juice element contents of Dan-ben-Hannah grapevines determined at harvest during the 2002/03 and 2003/04 seasons near Paarl in the Berg River Valley region.

\begin{tabular}{|c|c|c|c|c|c|c|}
\hline \multirow[t]{3}{*}{ Season } & \multicolumn{6}{|c|}{ Fertigation-crop load treatments } \\
\hline & $\mathbf{L F _ { N }}{ }_{N}^{(1)}$ & $\mathbf{L F}_{\mathbf{H}}$ & $\mathbf{W F}_{\mathrm{N}}$ & $\mathrm{WF}_{\mathrm{H}}$ & $\mathbf{D F}_{\mathrm{N}}$ & $\mathbf{D F}_{\mathrm{H}}$ \\
\hline & \multicolumn{6}{|c|}{$\mathbf{N}(\mathrm{mg} / \mathrm{L})$} \\
\hline $2002 / 03$ & $582 \mathrm{ab}^{(2)}$ & $527 \mathrm{~b}$ & $608 \mathrm{ab}$ & $558 \mathrm{ab}$ & $624 \mathrm{a}$ & $565 \mathrm{ab}$ \\
\hline \multirow[t]{2}{*}{$2003 / 04$} & $442 \mathrm{~b}$ & $428 \mathrm{~b}$ & $460 \mathrm{ab}$ & $449 \mathrm{~b}$ & $488 \mathrm{a}$ & $469 \mathrm{ab}$ \\
\hline & \multicolumn{6}{|c|}{$\mathrm{P}(\mathrm{mg} / \mathrm{L})$} \\
\hline $2002 / 03$ & $164 \mathrm{~b}$ & $152 \mathrm{~b}$ & $162 \mathrm{~b}$ & $151 \mathrm{~b}$ & $188 \mathrm{a}$ & $183 \mathrm{a}$ \\
\hline \multirow[t]{2}{*}{$2003 / 04$} & $178 \mathrm{~b}$ & $153 \mathrm{~b}$ & $167 \mathrm{~b}$ & $162 \mathrm{~b}$ & $192 \mathrm{a}$ & $194 \mathrm{a}$ \\
\hline & \multicolumn{6}{|c|}{$\mathrm{K}(\mathrm{mg} / \mathrm{L})$} \\
\hline $2002 / 03$ & $1706 \mathrm{a}$ & $1734 \mathrm{a}$ & $1724 \mathrm{a}$ & $1683 \mathrm{a}$ & $1606 \mathrm{a}$ & $1728 \mathrm{a}$ \\
\hline \multirow[t]{2}{*}{$2003 / 04$} & $2539 \mathrm{a}$ & $2467 \mathrm{a}$ & $2180 \mathrm{~b}$ & $2600 \mathrm{a}$ & $2593 \mathrm{a}$ & $2471 \mathrm{a}$ \\
\hline & \multicolumn{6}{|c|}{$\mathrm{Ca}(\mathrm{mg} / \mathrm{L})$} \\
\hline $2002 / 03$ & $31 \mathrm{a}$ & $32 \mathrm{a}$ & $33 \mathrm{a}$ & $33 \mathrm{a}$ & $29 \mathrm{a}$ & $27 \mathrm{a}$ \\
\hline \multirow[t]{2}{*}{$2003 / 04$} & $61 \mathrm{a}$ & $53 \mathrm{ab}$ & $44 \mathrm{~b}$ & $50 \mathrm{~b}$ & $51 \mathrm{ab}$ & $48 \mathrm{~b}$ \\
\hline & \multicolumn{6}{|c|}{$\operatorname{Mg}(\mathrm{mg} / \mathrm{L})$} \\
\hline $2002 / 03$ & $57 \mathrm{a}$ & $55 \mathrm{a}$ & $55 \mathrm{a}$ & $51 \mathrm{a}$ & $52 \mathrm{a}$ & $55 \mathrm{a}$ \\
\hline $2003 / 04$ & $53 \mathrm{a}$ & $48 \mathrm{~b}$ & $47 \mathrm{bc}$ & $46 \mathrm{bc}$ & $46 \mathrm{bc}$ & $44 \mathrm{c}$ \\
\hline
\end{tabular}

(1) Refer to Table 1 for more details of the treatments.

(2) Values designated by the same letter within each row do not differ significantly $(\mathrm{p} \leq 0.05)$. 
TABLE 10

Effect of low frequency (LF), weekly (WF) and daily pulse (DF) fertigation, as well as normal (N) and high (H) crop loads, on berry skin element contents of Dan-ben-Hannah grapevines determined at harvest during the 2002/03 and 2003/04 seasons near Paarl in the Berg River Valley region.

\begin{tabular}{|c|c|c|c|c|c|c|}
\hline \multirow[t]{3}{*}{ Season } & \multicolumn{6}{|c|}{ Fertigation-crop load treatments } \\
\hline & $\mathbf{L F}_{\mathrm{N}}^{(1)}$ & $\mathbf{L F}_{\mathrm{H}}$ & $\mathrm{WF}_{\mathrm{N}}$ & $\mathrm{WF}_{\mathrm{H}}$ & $\mathbf{D F}_{\mathrm{N}}$ & $\mathbf{D F}_{\mathrm{H}}$ \\
\hline & \multicolumn{6}{|c|}{$\mathbf{N}(\%)$} \\
\hline $2002 / 03$ & $0.99 \mathrm{~b}^{(2)}$ & $0.88 \mathrm{~b}$ & $0.98 \mathrm{~b}$ & $1.05 \mathrm{~b}$ & $1.26 \mathrm{a}$ & $1.28 \mathrm{a}$ \\
\hline \multirow[t]{2}{*}{$2003 / 04$} & $0.80 \mathrm{c}$ & $0.82 \mathrm{c}$ & $0.82 \mathrm{c}$ & $0.89 \mathrm{bc}$ & $1.27 \mathrm{a}$ & $1.02 \mathrm{~b}$ \\
\hline & \multicolumn{6}{|c|}{$\mathbf{P}(\%)$} \\
\hline $2002 / 03$ & $0.12 \mathrm{~b}$ & $0.13 \mathrm{ab}$ & $0.12 \mathrm{~b}$ & $0.13 \mathrm{ab}$ & $0.14 \mathrm{a}$ & $0.14 \mathrm{a}$ \\
\hline \multirow[t]{2}{*}{$2003 / 04$} & $0.15 \mathrm{~d}$ & $0.16 \mathrm{~cd}$ & $0.17 \mathrm{~cd}$ & $0.18 \mathrm{bc}$ & $0.23 \mathrm{a}$ & $0.20 \mathrm{~b}$ \\
\hline & \multicolumn{6}{|c|}{ K (\%) } \\
\hline $2002 / 03$ & $1.54 \mathrm{a}$ & $1.43 \mathrm{a}$ & $1.38 \mathrm{a}$ & $1.46 \mathrm{a}$ & $1.60 \mathrm{a}$ & $1.56 \mathrm{a}$ \\
\hline \multirow[t]{2}{*}{$2003 / 04$} & $1.79 \mathrm{~b}$ & $1.95 \mathrm{~b}$ & $1.98 \mathrm{~b}$ & $2.10 \mathrm{~b}$ & $2.81 \mathrm{a}$ & $2.65 \mathrm{a}$ \\
\hline & \multicolumn{6}{|c|}{$\mathrm{Ca}(\%)$} \\
\hline $2002 / 03$ & $0.19 \mathrm{a}$ & $0.20 \mathrm{a}$ & $0.21 \mathrm{a}$ & $0.24 \mathrm{a}$ & $0.18 \mathrm{a}$ & $0.22 \mathrm{a}$ \\
\hline \multirow[t]{2}{*}{$2003 / 04$} & $0.12 \mathrm{a}$ & $0.13 \mathrm{a}$ & $0.16 \mathrm{a}$ & $0.17 \mathrm{a}$ & $0.16 \mathrm{a}$ & $0.13 \mathrm{a}$ \\
\hline & \multicolumn{6}{|c|}{$\operatorname{Mg}(\%)$} \\
\hline $2002 / 03$ & $0.068 \mathrm{a}$ & $0.070 \mathrm{a}$ & $0.070 \mathrm{a}$ & $0.073 \mathrm{a}$ & $0.065 \mathrm{a}$ & $0.073 \mathrm{a}$ \\
\hline $2003 / 04$ & $0.075 \mathrm{a}$ & $0.081 \mathrm{a}$ & $0.085 \mathrm{a}$ & $0.093 \mathrm{a}$ & $0.091 \mathrm{a}$ & $0.089 \mathrm{a}$ \\
\hline
\end{tabular}

(1) Refer to Table 1 for more details of the treatments.

(2) Values designated by the same letter within each row do not differ significantly $(\mathrm{p} \leq 0.05)$.

similar to that of the $\mathrm{WF}_{\mathrm{H}}$ grapevines. In 2002/03, the DF strategy tended to promote the accumulation of $\mathrm{P}$ in the berry skins when compared to all the other treatments. In 2003/04, the berry skin $\mathrm{P}$ of $\mathrm{DF}_{\mathrm{N}}$ was substantially higher than that of LF and WF, regardless of crop load. The berry skins of yellow Sultanina raisins from the Lower Orange River region were found to have an average berry skin $\mathrm{P}$ content of $0.45 \%$ (Myburgh, 2003). In 2002/03, the DF grapevines tended to have more berry skin $\mathrm{K}$ than the grapevines in all the LF and WF treatments. During the 2003/04 season, berry skin $\mathrm{K}$ content was higher in the DF grapevines, regardless of crop load. Since berry skin K content ranging from $0.82 \%$ to $0.98 \%$ has previously been reported for yellow Sultanina raisins (Myburgh, 2003), it is evident that Dan-ben-Hannah berry skins have a much higher level. There were no treatment effects with respect to berry skin $\mathrm{Ca}$ and $\mathrm{Mg}$ contents.

\section{CONCLUSIONS}

In vineyards where daily fertigation is applied, the acidification of the soil directly beneath the drippers to the depth of the wetted zone is a major cause for concern, particularly in sandy soils. Furthermore, a notable amount of salts can accumulate around the edge of the small wetted soil volumes, which may cause problems if some of the salts are suddenly redistributed back into the root systems when rainfall occurs. These problems may also occur in the case of grapevines that are fertigated at a low frequency and weekly. It therefore is recommended that fertigated soils should be sampled regularly so that preventative measures, such as the adjustment of the fertiliser composition or the application of lime can be done, should these be necessary. Although it is possible that these salts are leached from the profile by the winter rains in Mediterranean climatic regions, the extent to which this leaching will occur is still unknown. In addition, salts that are leached to the subsoil could have a negative impact on the environment. This study has shown that daily fertigation results in the accumulation of $\mathrm{P}$ in leaf petioles, leaf blades, juice and berry skins. However, this could have implications for the $\mathrm{K}$ status of the grapevine, as there is a $\mathrm{P} / \mathrm{K}$ antagonism regarding nutrient uptake. Although increasing the crop load decreased the nutrient levels in the petioles, leaves and berries, the levels were still within the recommended norms, irrespective of crop load. Therefore, this study has shown that the accepted nutrient norms are sufficient to sustain higher than recommended crop loads in Dan-ben-Hannah grapevines.

\section{LITERATURE CITED}

Christensen, L.P., Peacock, W.L. \& Bianchi, M.L., 1991. Potassium fertilization of Thompson Seedless grapevines using two fertilizer sources under drip irrigation. Am. J. Enol. Vitic. 42, 227-232.

Clesceri, L.D., Greenberg, A.E. \& Eaton, A.D., 1998 (20 th ed). Standard methods for the examination of water and waste water. American Public Health Association, Washington DC. pp. 4-117 - 4-122.

Conradie, W.J., 1980. Seasonal uptake of nutrients by Chenin blanc in sand culture: I. Nitrogen. S. Afr. J. Enol. Vitic. 1, 59-65.

Conradie, W.J., 1981. Seasonal uptake of nutrients by Chenin blanc in sand culture: II. Phosphorus, potassium, calcium and magnesium. S. Afr. J. Enol. Vitic. 2, 7-13.

Conradie, W.J., 1994. Vineyard fertilisation. Proceedings of a workshop on vineyard fertilisation, Stellenbosch, 30 September 1994. ARC InfruitecNietvoorbij, Private Bag X5026, Stellenbosch, 7599, South Africa. 
Conradie, W.J., 2001. Timing of nitrogen fertilisation and the effect of poultry manure on the performance of grapevines on sandy soil. II. Leaf analysis, juice analysis and wine quality. S. Afr. J. Enol. Vitic. 21, 40-48.

Conradie, W.J. \& Myburgh, P.A., 2000. Fertigation of Vitis vinifera L. cv. Bukettraube/110 Richter on a sandy soil. S. Afr. J. Enol. Vitic. 21, 63-66.

Conradie, W.J. \& Saayman, D., 1989. Effects of long-term nitrogen, phosphorus, and potassium fertilization on Chenin blanc vines. II. Leaf analyses and grape composition Am. J. Enol. Vitic. 40, 91-98.

Falivene, S., 2005. Open hydroponics: risks and opportunities. Stage 1. General principles and literature review. Report to National Program for Sustainable Irrigation. Land and Water Australia, GPO Box 2181, Canberra ACT, Australia, 2601.

Hurndall, R., 2005. A guide to deciduous fruit of South Africa. Deciduous Fruit Producers' Trust. P.O. Box 163, 7622, Paarl, South Africa.

Klein, I., Strime, M., Fanberstein, L. \& Mani, Y., 2000. Irrigation and fertigation effects on phosphorous and potassium nutrition of wine grapes. Vitis $39,55-62$.

Komosa, A., Pacholak, E., Stafecka, A. \& Treder, W., 1999a. Changes in nutrient distribution in apple orchard soil as the effect of fertigation and irrigation. I. Ammonium and nitrates. J. Fruit Ornam. Plant Res. VII, 27-40.

Komosa, A., Pacholak, E., Stafecka, A. \& Treder, W., 1999b. Changes in nutrient distribution in apple orchard soil as the effect of fertigation and irrigation. II. Phosphorus, potassium and magnesium. J. Fruit Ornam. Plant Res. VII, 71-80.

Lategan, E.L., 2011. Determining of optimum irrigation schedules for drip irrigated Shiraz vineyards in the Breede River Valley. Thesis, Stellenbosch University, Private Bag X1, 7602 Matieland, South Africa.

Le Roux, E.G., 1974. A climate classification for the South Western Cape viticultural areas (in Afrikaans). Thesis, Stellenbosch University, Private Bag X1, 7602 Matieland, South Africa.
Myburgh, P.A., 1996. Response of Vitis vinifera L. cv. Barlinka/Ramsey to soil water depletion levels with particular reference to trunk growth parameters. S. Afr. J. Enol. Vitic. 17, 3-14.

Myburgh, P.A., 2003. Responses of Sultanina to water deficits during various phases. S. Afr. J. Enol. Vitic. 24, 25-33.

Myburgh, P.A., 2012. Comparing irrigation systems and strategies for table grapes in the weathered granite-gneiss soils of the Lower Orange River region. S. Afr. J. Enol. Vitic. 33, 184-197.

Myburgh, P.A. \& Howell, C.L., 2007. Responses of Sunred Seedless and Muscat Supreme to irrigation during berry ripening. I - Growth, yield and juice analyses. SA Fruit Journal Dec 06/Jan 07, 48-53.

Myburgh, P.A. \& Howell, C.L., 2012. Comparison of three different fertigation strategies for drip irrigated table grapes - Part I. Soil water status, root system characteristics and plant water status. S. Afr. J. Enol. Vitic. 33, 264-274.

Reynolds, A.G., Lowrey, W.D. \& De Savigny, C., 2005. Influence of irrigation and fertigation on fruit composition, vine performance, and water relations of Concord and Niagara grapevines. Am. J. Enol. Vitic. 56, 110128.

Richards, L.A., 1954. Diagnosis and improvement of saline and alkaline soils. Agriculture Handbook No. 60, U.S. Dept. Agric., U.S. Government Printing Office Washington D.C.

Saayman, D., 1981. Wingerdvoeding. In: Burger, J. \& Deist, J. (eds) Wingerdbou in Suid-Afrika. Nietvoorbij, Stellenbosch, South Africa. pp. $343-383$

Saayman, D. \& Lambrechts, J.J.N., 1995. The effect of fertilisation on the performance of Barlinka table grapes on sandy soil, Hex River Valley. S. Afr. J. Enol. Vitic. 16, 41-49.

Treder, W., 2005. Variation in soil $\mathrm{pH}$, calcium and magnesium status influenced by drip irrigation and fertigation. J. Fruit Ornam. Plant Res. 13, $59-70$

Winkler, A.J., 1962. General viticulture. University of California Press, Los Angeles. 